rationale og svigter dermed at levere det nødvendige grundlag for en reel reformering af uddannelsessystemet.

Anders Draby Sorensen

\section{Agamben, Agamben og mere Agamben: Eden og nøgenheden}

Giorgio Agamben: Nogenhed, oversat og med efterskrift af Lars Östman (og billeder), Forlaget Anis 2012, 176 sider, 248 kr.

Sprogets sakramente. En arkaologi for eden (Homo sacer $(I, 3)$, oversat og med forord af Soren Gosvig Olesen, Forlaget Wunderbuch 2012, 120 sider, $229 \mathrm{kr}$.

Dette er en anmeldelse af to nye oversættelser af den italienske filosof, jurist og idéhistoriker Giorgio Agamben (f. 1942). Nogenhed er en oversætelse af tekstsamlingen Nuditá fra 2009, som er en samling af kortere tekster og essays, hvoraf nogle bygger på forelæsninger. På nær teksten Hvad er det samtidige?, som tidligere er blevet udgivet i Agambens Hvad er et dispositiv? - og to andre essays, Forlaget Slagmark 2010, er teksterne nye på dansk. Nogenhed er som sådan et enkeltstående værk med en masse små analyser, der (næsten) alle kredser om (den nøgne) krop. Nogenhed kan dog med stor fordel læses, som også oversætteren Lars Östman gør opmærksom på i sit fine efterskrift (der er (en del) længere end den længste Agamben-tekst), som en del af Agambens Homo sacer projekt, hvor spørgsmålet om det nøgne liv netop spiller en afgørende rolle. Sprogets sakramente fra 2008 er derimod formelt en del af Homo sacer serien (helt præcist nr. II,3), der indtil videre omfatter Homo sacer. Den suvercne magt og det nogne liv (1995), Resterne fra Auschwit: Arkivet og vidnet (Homo Sacer III) (1998), Undtagelstilstand (Homo sacer II,1) (2003), Riget og herligheden (Homo sacer II,2) (2007), og altså så Sproget sakramente (Homo sacer II,3) og nu også de helt nye Den hojeste fattigdom. Klosterregler og livsform (Homo sacer IV,1) (2011) og Opus dei. Embedets arkecologi (Homo sacer II,5) (2012). Både Sprogets sakramente og Nogenhed skriver sig dermed også ind i den drejning Agamben tog særligt fra Riget og herligheden fra et fokus på romerretten til i høj grad at koncentrere sig 
om kirkefædre og den tidlige kristne tradition (og dens konsekvenser og indflydelser på den vestlige ret og magt). Sprogets sakramente og Nogenhed skriver sig også ind i en veritabel bølge af Agamben-oversættelser, der er skyllet ind over Danmark de seneste par år, hvor Undtagelsestilstand kom i 2009 på forlaget Philosophia, Hvad er et dispositiv? som næunt 2010, Resterne fra Auschwitz, er kommet 2012 på Kunstakademiets Billedkunstskoler, ligesom Homo sacer, efter mange år undervejs, også burde være kommet det fra Klim.

Nogenhed er som næunt en tekstsamling (bestående af 11 tekster), hvor den mindste er på to sider og den længste (der også har givet samlingen sit navn) er på 27, der (næsten) alle kredser om det samme emne, men som i særdeleshed er bundet sammen (for dem der kender til Agamben) i forhold til de emner og spørgsmål han kredser om i Homo sacer projektet. Homo sacer projektet drejer sig helt grundlæggende om at spore (arkæologisk og genealogisk - med stor inspiration fra Michel Foucault) rødderne til den særlige (biopolitiske) regering af mennesker, som kendetegner magten i Vesten. Det er dette forhold, der spores med udgangspunkt $i$ en lang række tænkere, som nævnt Foucault, men også særligt Martin Heidegger, Carl Schmitt og Walter Benjamin og som tager udgangspunkt i undersøgelser af nogle en gang imellem temmelig bizzare emner (som også kan ses af titlerne ovenfor) som f.eks. kirkefædre fra det 2. til det 5. århundredes brug af termen oikonomia til at forklare hvordan Gud både kunne være én og tre (i treenigheden) i Riget og herligheden, og de seneste værkers fokus på embedet og klosterliv. Således er Nogenhed en (agambiansk perle)række af analyser af underfundige emner som f.eks. i det titel-givende essay "Nøgenhed", der tager udgangspunkt i selve begyndelsen, om man så må sige, med en analyse af tøjets teologi og afgørende status i den vestlige filosofi fra Adam og Eva i Paradisets have, der efter at have spist af xblet fra Kundskabens træ synder for første gang og "Således åbnede de begge øjnene og så, at de var nøgne (citeret fra Agamben og ikke fra Bibelen), der efterfølges af en agambiansk tour de force i den vesterlandske tænkning, med udgangspunkt i kirkefædrene, og dens forhold til kroppen, nøgenheden, tøjet, livet og 
skammen. På den måde er linket til Homo sacer projektet tydeligt med dets fokus på det nøgne liv, menneskets reduktion til den rene biologi, som går igennem hele Nogenhed, hvor vi får analyser af Kafkas K som kalumniator, som selv-anklagende, genopstandelsens problem $\mathrm{i}$ forhold til kroppen, overgangen i strafferetten fra den personlige tilståelse til det biologiske fingeraftryk og senere DNA'en og oksesult (boulimos, bulimien) som en særlig inoperativ måde at spise på, hvor formålstjenesteligheden (det at blive mæt) er blevet forskudt til fordel for en ren spisen, den rene aktivitet. Nogenhed leverer således en række spændende analyser (nogle bedre end andre, som det også ofte er tilfældet med Agamben), der dog nok særligt har interesse for dem, der i forvejen kender til Agamben og netop læst som perspektiver på og indspark til Homo sacer projektet.

I modsætning til Nogenhed er Sprogets sakramente officielt en del af Homo sacer projektet. Sprogets sakramente handler helt grundxggende, som undertitlen En arkecologi for eden også afslører, om eden. Agamben undersøger her det forhold i sproget, eden, som en særlig slags ytring, der understøtter, garanterer og beviser handlinger. Eden har ikke noget at gøre med selve udsagnet, men er garantien for dets virkningsfuldhed. Det er forbindelsen mellem ord og handling og er dermed afgørende for tillid, tro, pålidelighed, troværdighed (tro på latin er credo, hvoraf vores 'kredit' kommer fra). Eden for Agamben er på den måde afgørende for mennesket som sådan fordi den er en afgørende del af selve vores sprog og særligt som politisk væsen eftersom eden bliver central i forbindelse med forhold mellem mennesker, ret, lov, politiske pagter, troværdighed, osv. Bogen (eller nærmere essayet) sporer så edens oprindelse i diverse græske og romerske tekster og også dets beslægtede og indbyggede fænomener såsom meneden, forbandelsen, bandeordet og fordømmelsen. Til allersidst kommer vi igen op til overfladen og får nogle overordnede refleksioner som giver os nogle hints til hvordan vi kan forbinde det med Homo sacer projektet og Agambens øvrige arbejde. Her skriver Agamben f.eks. : "Lige så meget om endnu ikke afgørende må det have været for det levevæsen, der opdagede talens mulighed, om dets ord 
havde virkning og var sandfærdige, dvs. det må have været et lige så afgørende problem, hvordan man sikrede den oprindelige forbindelse mellem navnene og tingene, og mellem det subjekt, der er blevet talende - og følgelig i stand til at påstå og love - og dets handlinger." Det har altså drejet sig for Agamben at anskue menneskets og sprogets oprindelse, ikke som naturvidenskaben og lingvistikken som et udelukkende kognitivt problem, "som om det at blive menneske kun handlede om intelligens og hjernekapacitet og ikke også om ethos, som om intelligensen og sproget ikke også og især rejste spørgsmål af etisk og politisk art, som om bomo sapiens ikke også, og kan hænde netop derfor, var homo iustus." Mennesket er derfor, som udgangspunkt i hvert fald også, et politisk dyr, hvor det fra starten har været et problem, noget der skulle tænkes over, at regulere forholdet mellem mennesker. Rettens problem og edens problem er dermed konstitutive for mennesket og er indeholdt i selve sproget. En stor del af problematikken for Agamben går derfor også her på den normale opdeling $i$ en retslig og en før-retslig tilstand, og derfor søger han at vise, at retten, eden, politikken og religionen altid har været dybt infiltrerede $i$ hinanden og ikke som sådan kan adskilles. For at eksemplificere denne centrale tanke hos Agamben kan vi vende tilbage til Nogenhed, hvor Agamben, i teksten "Skabelse og frelse" skriver noget, som er kendetegnende for hans vending de sidste par år, nemlig at "Gud er stedet, hvor menneskene tænker over deres afgørende problemer". Der er ikke noget skarpt skel mellem religion, teologi, politik, økonomi, ret, etc., men de grundlæggende retslige og politiske spørgsmål er fra starten tænkt i teologiske termer (der så er tænkt i administrative, praktiske, 'økonomiske' termer). Derfor også vigtigheden af at undersøge denne tradition. Desværre for Sprogets sakramente ender den med at blive til det, der en gang imellem går galt for Agamben, nemlig med en interessant indledning og problemstilling, der så forsvinder i en lang og esoterisk udredning af nogle lidt mærkelige tekster, for så igen at dukke op helt til sidst med nogle spændende perspektiver (det er der også lidt af i essayet "Nøgenhed"). Men det er måske også for dem der, som denne anmelder, finder Agamben mest interessant som politisk tænker og som ser 
Riget og herligheden som det klart mest interessante af hans værker og derfor ikke er så interesseret i Agamben som sprog- eller eksistensfilosof - hvilket Sprogets sakramente lægger sig tæt op af (og som også var den filosofi Agamben bedrev før han hengav sig til Homo sacer projektet). På den måde er Sprogets sakeramente et underligt lille værk, som nok ikke vil finde interesse hos andre end de hardcore Agamben-fans, og som man derfor, til trods for det bestemt beundringsværdige heri, kan undre sig lidt over er blevet oversat til dansk. Det samme kunne man sige var tilfældet for Nogenhed, men her er trods alt en lidt bredere appel, eftersom også bare almindelige Agamben-interesserede (og ikke kun de hardcore-fans) vil kunne finde den interessant, netop fordi den leverer nogle sjove analyser og undersøgelser og på den måde giver fine perspektiver på Agambens arbejde for dem der kender lidt til ham. Men om det giver mening for så mange andre må så forblive et åbent spørgmål. Men indtil videre, og uanset, kan vi jo glæde os over den øgede Agamben-interesse i vores lille land.

Mathias Hein Jessen

\section{Regeringens genea-} logi

Giorgio Agamben: The Kingdom and the Glory, Stanford University Press, 2011,328 sider, 24,95 USD.

Fire år efter sin udgivelse er den italienske idéhistorikers Il regno e la gloria langt om længe udkommet på engelsk. Udgivelsen indgår i Agambens Homo Sacer-projekt, der i skrivende stund tæller syv udgivelser. Fra de overvejende filosofiske overvejelser i de tidlige Homo Sacer-udgivelser har Agamben i stigende grad bevæget sig imod en mere idéhistorisk kritik - à la den franske idéhistoriker Michel Foucault - og denne finder indtil videre sit absolutte højdepunkt $\mathrm{i}$ The kingdom and the glory.

Ifølge Agamben er den vestlige politiske tænkning gået galt i byen. Lidt kækt kan man sige, at Agamben i The kingdom and the glory fordobler Tertullians kritik af forskningen i politik helt tilbage fra de første århundreder: "Mens latinere har det med at udbryde 'monarki', nægter selv grækere at forstå økonomien" (Tertullian citeret i Agamben 2011a: 14). Det politiske spørgs- 